\title{
Acidification alters the composition of ammonia-oxidizing microbial assemblages in marine mesocosms
}

\author{
Jennifer L. Bowen ${ }^{1, *}$, Patrick J. Kearns ${ }^{1}$, Michael Holcomb ${ }^{2,4}$, Bess B. Ward ${ }^{3}$ \\ ${ }^{1}$ Biology Department, University of Massachusetts Boston, Boston, Massachusetts 02125, USA \\ ${ }^{2}$ Department of Marine Geology and Geophysics, Woods Hole Oceanographic Institution, Woods Hole, Massachusetts 02543, USA \\ ${ }^{3}$ Department of Geosciences, Princeton University, Princeton, New Jersey 08544, USA \\ ${ }^{4}$ Present address: ARC Centre of Excellence in Coral Reef Studies, The University of Western Australia, Crawley, \\ Western Australia 6009, Australia
}

\begin{abstract}
Increasing atmospheric $\mathrm{CO}_{2}$ concentrations are causing decreased $\mathrm{pH}$ over vast expanses of the ocean. This decreasing $\mathrm{pH}$ may alter biogeochemical cycling of carbon and nitrogen via the microbial process of nitrification, a key process that couples these cycles in the ocean, but which is often sensitive to acidic conditions. Recent reports have indicated a decrease in oceanic nitrification rates under experimentally lowered $\mathrm{pH}$. How the composition and abundance of ammonia-oxidizing bacteria (AOB) and archaea (AOA) assemblages respond to decreasing oceanic $\mathrm{pH}$ is unknown. We sampled microbes from 2 different acidification experiments and used a combination of $\mathrm{qPCR}$ and functional gene microarrays for the ammonia monooxygenase gene $(a m o A)$ to assess how acidification alters the structure of ammonia oxidizer assemblages. We show that despite widely different experimental conditions, acidification consistently altered the community composition of AOB by increasing the relative abundance of taxa related to the Nitrosomonas ureae clade. In one experiment, this increase was sufficient to cause an increase in the overall abundance of AOB. There were no systematic shifts in the community structure or abundance of AOA in either experiment. These different responses to acidification underscore the important role of microbial community structure in the resiliency of marine ecosystems.
\end{abstract}

KEY WORDS: Ocean acidification - Ammoniaoxidizing archaea . Ammonia-oxidizing bacteria . Nitrification

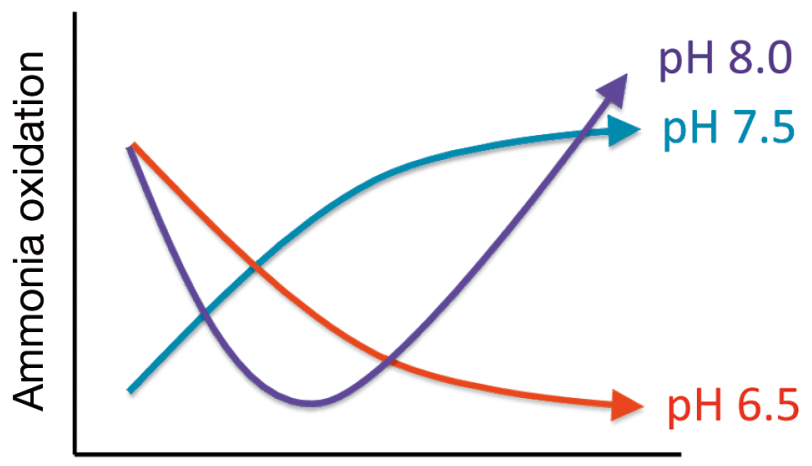

$\triangle$ AOA $A O B$ over time

Changes in microbial community structure under different $\mathrm{pH}$ regimes make it difficult to predict geochemical responses such as ammonia oxidation.

Image: $B$. Ward

\section{INTRODUCTION}

Increasing atmospheric $\mathrm{CO}_{2}$ has already led to decreased oceanic pH (Feely et al. 2004, Orr et al. 2005, Doney et al. 2009), but the effect that this decreasing $\mathrm{pH}$ will have on global carbon and nitrogen cycling is debated. Some have argued that, aside from calcification, $\mathrm{pH}$ change in the ocean will not fundamentally alter marine biogeochemistry (Joint et al. 2011). Nevertheless, significant reductions (8-38\%) in ammonia oxidation rates were reported from shortterm acidification experiments in the open ocean (Beman et al. 2011), and water column incubations from the English Channel showed a near complete 
cessation of ammonia oxidation at pH 6.5 (Kitidis et al. 2011). In artificially acidified lakes, Rudd et al. (1988) also observed the complete shutdown of nitrification at $\mathrm{pH}$ below 5.7. Altered $\mathrm{pH}$ has also been shown to shift the overall structure of microbial communities (Krause et al. 2012). Ammonia oxidation, the first step in nitrification $\left(\mathrm{NH}_{3}+1.5 \mathrm{O}_{2} \rightarrow \mathrm{NO}_{2}{ }^{-}+\right.$ $\mathrm{H}_{2} \mathrm{O}+\mathrm{H}^{+}$), is thought to be $\mathrm{pH}$ sensitive (1) due to feedback inhibition through acidification of the medium and (2) because $\mathrm{NH}_{3}$, rather than $\mathrm{NH}_{4}{ }^{+}$(the dominant form at $\mathrm{pH}<9.3$ ), is the substrate in the first step of the ammonia oxidation reaction. Given the importance of nitrification as both a source of oxidized nitrogen and a control on primary production in the oceans (Yool et al. 2007), understanding how ammonia-oxidizing communities respond to acidification is imperative.

\section{MATERIALS AND METHODS}

We opportunistically sampled from 2 very different experiments designed to test the effects of acidification on (1) diatom bloom development and (2) the temperate coral Astrangia poculata (Holcomb et al. 2012). In the diatom bloom experiment, 1801 of seawater collected from a depth of $70 \mathrm{~m}$ in Monterey Bay, California (USA), were inoculated with 201 of surface seawater and incubated under ambient light for $6 \mathrm{~d}$. One of the barrels was acidified using concentrated $\mathrm{HCl}$ (accompanied by bicarbonate addition to maintain alkalinity; Shi et al. 2009). An Oakton pH 11 meter (with an Oakton 35811-71 probe) was used to measure $\mathrm{pH}$. The meter was inter-calibrated with spectrophotometric measurements using thymol blue (Zhang \& Byrne 1996). pH of the ambient and acidified barrels evolved over the experiment, but $\mathrm{pH}$ in the acidified barrel was $\sim 0.21 \mathrm{pH}$ units lower than the ambient barrel through most of the experiment. A phytoplankton bloom dominated by diatoms developed in both barrels and the time courses of chlorophyll accumulation and nitrate drawdown were essentially identical (data not shown). Ammonia-oxidizing bacteria (AOB) and archaea (AOA) samples were collected after the initial acidification and $6 \mathrm{~d}$ later by filtering 21 of water into capsule filters using a peristaltic pump. Ammonium concentrations were not measured, but previous reports indicate that the concentrations in Monterey Bay at this depth are low, averaging $0.25 \mu \mathrm{M}$ (Kudela \& Dugdale 2000). Initial ammonium concentrations in similar barrel experiments performed previously with Monterey Bay seawater were on the order of $1.0 \mu \mathrm{M}$
(Fawcett \& Ward 2011). The fraction present as $\mathrm{NH}_{3}$ (shown to be the substrate limiting ammonia oxidation, at least in $\mathrm{AOB}$ ) is $<5 \%$ and $<3 \%$ of the total $\mathrm{NH}_{3}+\mathrm{NH}_{4}{ }^{+}$at $\mathrm{pH} 7.89$ and 7.69 , respectively, assuming a pK of 9.23.

In the Vineyard Sound coral experiment, 1.91 tanks $(\mathrm{n}=4)$ containing live coral Astrangia poculata were incubated with flowing seawater from Vineyard Sound, Massachusetts (USA), maintained at $24^{\circ} \mathrm{C}$. Ambient $\mathrm{CO}_{2}$ tanks were maintained at a daytime $\mathrm{pH}$ of $8.00 \pm 0.04$ (night time $\mathrm{pH}$ in all tanks was up to 0.1 lower). Acidified tanks were maintained at a daytime $\mathrm{pH}$ of $7.8 \pm 0.04$ by bubbling incoming seawater with 800 ppm $\mathrm{CO}_{2}$. Both ambient and $\mathrm{CO}_{2}$-enriched experiments were performed with and without addition of inorganic nutrients. Nutrient-enriched tanks were supplied with seawater supplemented with $\mathrm{NaNO}_{3}$, $\mathrm{K}_{2} \mathrm{HPO}_{4}$, and $\mathrm{FeCl}_{2}$ solutions. $\mathrm{NO}_{3}$ was elevated by $5 \mu \mathrm{M}, \mathrm{PO}_{4}$ by $0.3 \mu \mathrm{M}$, and Fe by $2 \mathrm{nM}$ above ambient values. Ammonium concentrations $\left(\mathrm{NH}_{3}+\mathrm{NH}_{4}{ }^{+}\right)$ ranged from undetectable to $1.1 \mu \mathrm{M}$, and there was no significant difference between control and acidified tanks, either initially or at the final sampling time. $\mathrm{NH}_{3}$ comprises $<6 \%$ and $<4 \%$ of the total $\mathrm{NH}_{3}+\mathrm{NH}_{4}{ }^{+}$at $\mathrm{pH} 8.0$ and 7.8 , respectively. Tanks were maintained for 5 mo under treatment conditions with regular removal of wall growth from the sides and bottoms of the tanks. Cleanings were suspended for approximately $3 \mathrm{wk}$ before collecting biofilm material from the tank walls for genomic analysis. Additional details of the Vineyard Sound coral experiment have been published (Holcomb et al. 2012).

DNA was extracted from the Monterey Bay filters using the Puregene DNA kit (Gentra) and from the tank biofilm using the MoBio PowerSoil DNA extraction kit (MoBio Laboratories). AOA and AOB community composition was analyzed using functional gene microarrays containing archetype probes representing all known AOA and AOB amoA gene sequences (as of November 2009; Bouskill et al. 2011, 2012a). Target DNA was labeled from whole genomic DNA extracts using Klenow amplification (Ward 2008). Hybridization to the array, array scanning, and initial data quality assessment/control have been previously described (Bouskill et al. 2011, 2012a). The contribution of each archetype to the total community is indicated by its relative fluorescence ratio (RFR), the portion of the total fluorescence signal represented by that archetype (Ward et al. 2007). Correspondence analysis of the archetype RFR was performed using the 'cca' function contained in the $\mathrm{R}$ programming language package 'vegan' (Oksanen et al. 2011). Analysis of similarities 
was performed using the anosim function in 'vegan' (Oksanen et al. 2011). Microarray data are archived at the Microarray Gene Expression Omnibus (accession number: GSE49956).

$\mathrm{AOA}$ and $\mathrm{AOB}$ gene abundances were quantified from extracted DNA using QuantIt ${ }^{\mathrm{TM}}$ PicoGreen ${ }^{\circledR}$ dsDNA reagent (Life Technologies) in triplicate reactions. Each sample was normalized to a concentration of $3 \mathrm{ng} \mathrm{\mu l}^{-1}$ prior to quantification of the amoA gene via quantitative PCR on an Agilent MX3005p qPCR system. Archaeal amoA genes were quantified in triplicate using $0.2 \mu \mathrm{M}$ of primers Arch-amoAF (5'-STA ATG GTC TGG CTT AGA CG-'3) and ArchamoAR (5'-GCG GCC ATC CAT CTG TAT GT-'3) (Francis et al. 2005), along with $10 \mu \mathrm{l}$ of $\mathrm{SYBR}^{\circledR}$ Green Brilliant III Ultra-Fast master mix, $3 \mathrm{mM} \mathrm{MgCl}_{2}$ (final concentration), and $300 \mathrm{\mu g} \mathrm{ml}^{-1} \mathrm{BSA}$ in a $20 \mu \mathrm{l}$ reaction. Reaction conditions included an initial denaturation at $95^{\circ} \mathrm{C}$ followed by 42 cycles of $1 \mathrm{~min}$ at $94^{\circ} \mathrm{C}$, $1.5 \mathrm{~min}$ at $59^{\circ} \mathrm{C}$, and $1.5 \mathrm{~min}$ at $72^{\circ} \mathrm{C}$ followed by a final denaturation to generate a melt curve to test for amplification stringency. Bacterial amoA genes were quantified in triplicate using $0.1 \mu \mathrm{M}$ of primers amoA-1F (5'-GGG GTT TCT ACT GGT GGT-'3) and amoA-2R (5'-CCC CTC KGS AAA GCC TTC TTC-'3) (Rotthauwe et al. 1997), along with $10 \mu \mathrm{l}$ of SYBR ${ }^{\circledR}$ Green Brilliant III Ultra-Fast master mix, and $300 \mu \mathrm{g}$ $\mathrm{ml}^{-1} \mathrm{BSA}$ in a $20 \mu \mathrm{l}$ reaction. Reaction conditions included an initial denaturation at $95^{\circ} \mathrm{C}$ followed by 42 cycles of $1 \mathrm{~min}$ at $94^{\circ} \mathrm{C}, 1.5 \mathrm{~min}$ at $59^{\circ} \mathrm{C}$, and $1.5 \mathrm{~min}$ at $72^{\circ} \mathrm{C}$ followed by a final denaturation to generate a melt curve to test for amplification stringency. All PCR products were visualized on a $1.5 \%$ agarose gel to assure proper fragment length. Amplification efficiencies varied from 78 to $85 \%$.

\section{RESULTS AND DISCUSSION}

After only $6 \mathrm{~d}$, changes were evident in the AOB assemblage in the Monterey Bay seawater incubations (Fig. 1). There was a $10 \%$ increase in the RFR of archetype B17 (Nitrosomonas ureae clade), from $47 \%$ of the fluorescence signal in the acidified barrel on Day 1 to $57 \%$ of the signal on Day 6 . This increase, along with an increase in archetype B16, resulted in a shift to the upper left in the correspondence analysis of the acidified barrel AOB community structure (Fig. 1A). However, little change occurred in the community structure of the ambient barrel between Day 1 and Day 6 (Fig. 1). Although AOB are thought to turn over slowly, this somewhat rapid shift in community structure is not without precedent; Nicol et al.
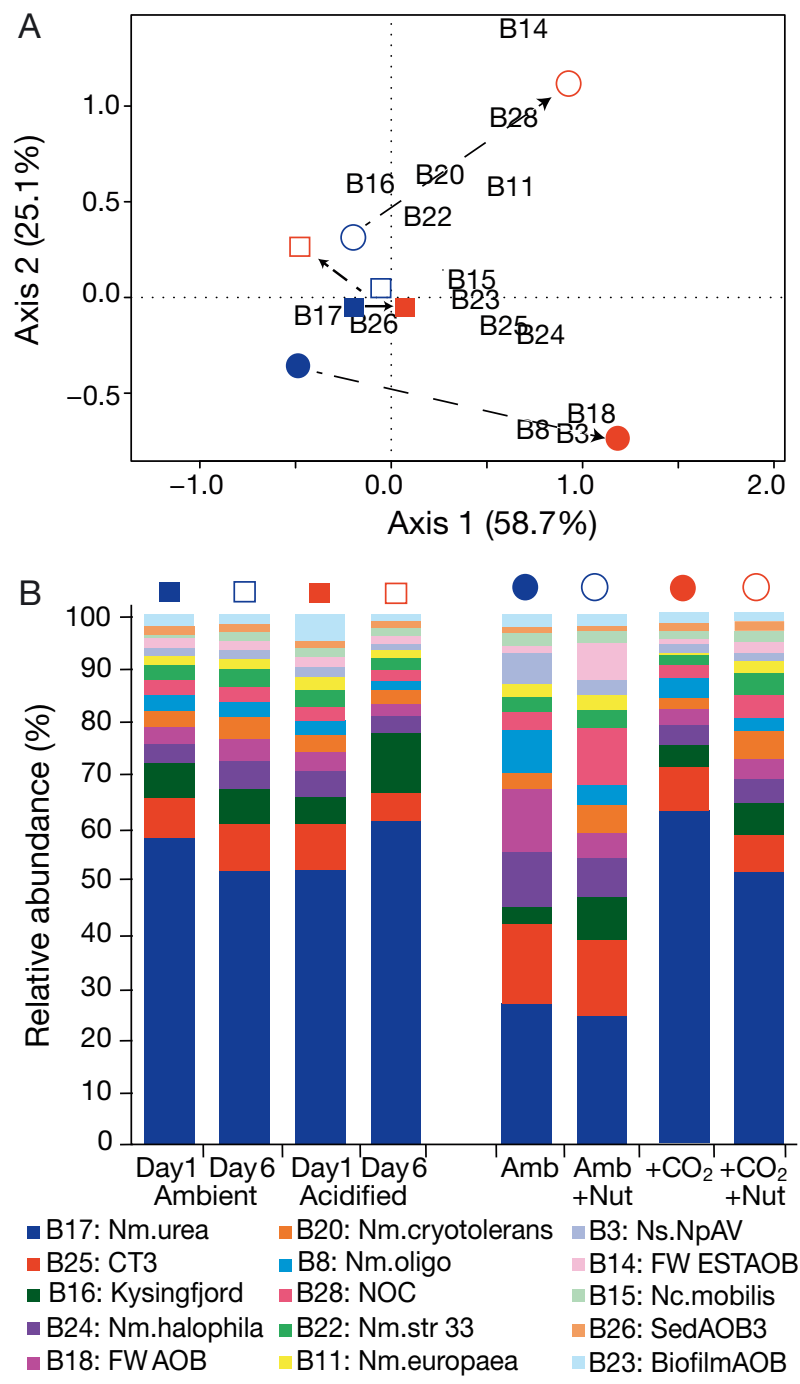

Fig. 1. Community composition of ammonia-oxidizing bacteria (AOB) in 2 different acidification experiments. (A) Correspondence analysis of community similarities in both experiments: Expt 1 (squares), Monterey Bay seawater experiment; Expt 2 (circles), Vineyard Sound coral experiment. Blue symbols indicate ambient $\mathrm{CO}_{2}$ concentrations and red symbols indicate acidified samples. Arrows indicate the direction of change from the ambient to the acidified treatment. (B) The most abundant archetypes that explain the ordination patterns for both experiments. Symbols above each column correspond to symbols in the ordination plot. See Appendix Table A1 for full archetype probe list (modified from Bouskill et al. 2011)

(2008) demonstrated a decrease in $\mathrm{NH}_{4}{ }^{+}$concentrations in as little as $2 \mathrm{~d}$ and a shift in community structure within $2 \mathrm{wk}$ in soil mesocosms of varying acidity.

In the 3 wk long Vineyard Sound coral experiment, the biofilm community demonstrated an even stronger response by the Nitrosomonas ureae clade (Fig. 1). Archetype B17 increased from approximately $23 \%$ of the AOB signal in the ambient tanks (Fig. 1), to over 
$54 \%$ in the acidified tanks (Fig. 1) and resulted in a clear separation of the 2 acidified samples along the primary axis (explaining $58.7 \%$ of the variance) in the correspondence analysis. The partitioning of the acidified samples along the secondary axis (explaining $25.1 \%$ of the variance) results from different AOB archetypes being abundant in the 2 ambient tanks (archetypes B18, B8, and B3 in the ambient tank, archetypes B14 and B28 in the ambient plus nutrients tank), but all being reduced to low levels in the acidified tanks. For both experiments, analysis of similarities indicates that the AOB display a significant difference in community composition between acidified and ambient treatments $(\mathrm{R}=0.631, \mathrm{p}=0.036)$.

By contrast, the AOA indicated no such systematic shifts in community composition in either acidifica-
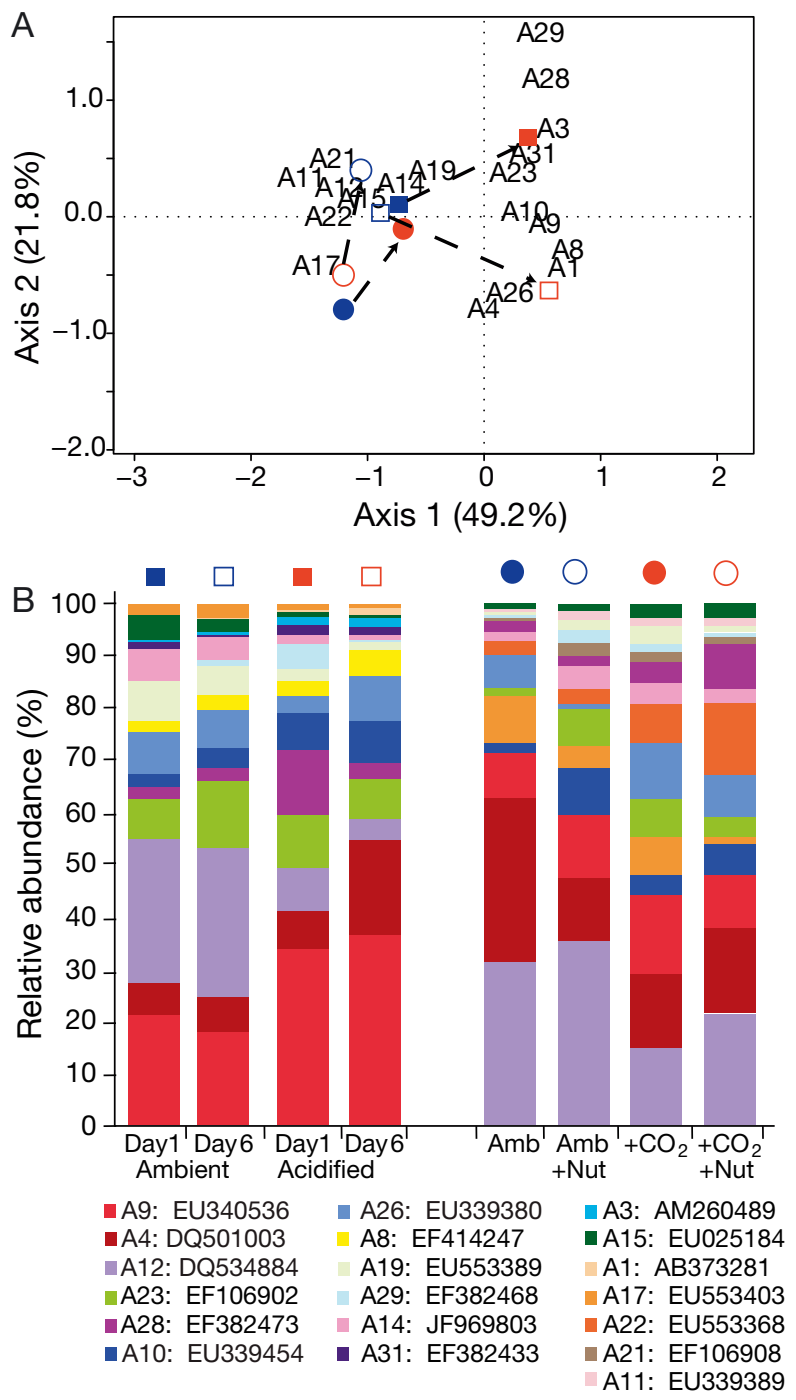

Fig. 2. As in Fig. 1, but for community composition of ammonia-oxidizing archaea (AOA). See Appendix Table A2 for full archetype probe list (modified from Bouskill et al. 2012a) tion experiment (Fig. 2). In the Monterey Bay seawater experiment, AOA archetype A9 comprised a greater proportion of the community in the acidified barrels, whereas archetype A12 was more important in the ambient barrels (Fig. 2B), but this difference was due to different initial starting communities and did not change over the course of the experiment, thus the change cannot be attributed to a treatment effect. The differences in these 2 archetypes help to explain the separate partitioning of the acidified barrel, but the ambient barrel showed little change in the community over the course of the experiment. Thus, the remaining samples generally form 1 cluster of points with no clear segregation among the AOA as a result of the acidification (Fig. 2A) and no clear pattern in dominance of any one AOA archetype as a function of treatment (Fig. 2B). This result is further supported by a lack of difference with treatment as indicated by analysis of similarities $(\mathrm{R}=0.097, \mathrm{p}=0.233)$.

We quantified the abundance of AOA and AOB in DNA extracted from both experiments via qPCR. We obtained widely different estimates of the relative importance of the 2 groups. The absolute gene abundances between the 2 experiments are not directly comparable, however. While both experiments are normalized to the total mass of DNA, the Monterey Bay seawater experiment is normalized to the mass of DNA extracted from 21 of sea water and the Vineyard Sound coral experiment is normalized to $0.5 \mathrm{~g}$ wet weight biofilm material. Importantly, however, the relative abundances of $\mathrm{AOA}$ and $\mathrm{AOB}$ within each experiment are comparable, as are their changes as a result of acidification.

In the Monterey Bay seawater experiment (Fig. 3), both AOA and AOB amoA copies decreased from Day 1 to Day 6 of the experiment, suggesting that both communities were in decline. The declines, however, appeared to be slightly less severe in the acidified barrel, particularly for AOA where the gene abundances were already quite low. Surprisingly, AOB considerably outnumbered AOA in this Monterey Bay seawater experiment. Previous work by Mincer et al. (2007) reported AOB concentrations in Monterey Bay seawater that were largely undetectable through most of the upper $200 \mathrm{~m}$ of the surface ocean. Santoro et al. (2010), however, also reported $\mathrm{AOA} / \mathrm{AOB}$ amoA quantities in the nearby Central California Current. While AOA were frequently more abundant than AOB, AOB sometimes outnumbered AOA at the depths sampled in this acidification experiment. Although the primers of Rotthauwe et al. (1997) do not detect the gammaproteobacterial ammonia oxidizers, the microarray 


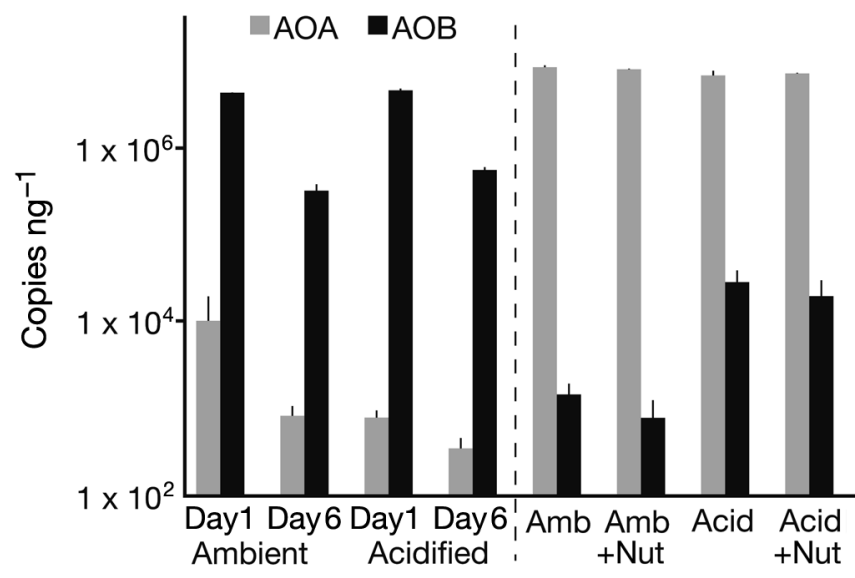

Fig. 3. Mean (+SD) amoA gene abundance of ammoniaoxidizing archaea (AOA) and bacteria (AOB) from the Monterey Bay seawater experiment (left side) and the Vineyard Sound coral experiment (right side) as determined by quantitative PCR. Data are from triplicate $\mathrm{qPCR}$ reactions

probe that binds Nitrosococcus sequences accounted for only 2.0 to $2.6 \%$ of the relative fluorescence signal, suggesting that the abundance of this gammaproteobacterial AOB were sufficiently low and uniform that their omission from the qPCR amplification does not change the observed trends.

By contrast, in the Vineyard Sound coral experiment, AOA were the dominant group and, consistent with the lack of community change in the microarray results, the AOA did not change in abundance as a result of acidification (Fig. 3). Contrary to our expectations, however, the AOB amoA gene abundance increased in both acidification treatments from an average of approximately 1200 gene copies per ng DNA in the ambient treatment to over 25000 copies, on average, in the acidified treatments. This 20 -fold increase in gene abundance coincides with a dramatic increase in the relative fluorescence of the $\mathrm{B} 17$ probe on the microarray, suggesting that representatives of this clade were responsible for the increased gene abundances of AOB. As with the Monterey Bay experiment, the probe that binds Nitrosococcus sequences accounted for less than $10 \%$ of the AOB relative fluorescence signal for these samples, suggesting that if the gammaproteobacteria were included in the qPCR it would not alter the results that demonstrate a large increase in AOB abundance in the acidified samples.

The results from these widely different experiments illustrate a few key points regarding the potential response of ammonia oxidizers to ocean acidification. First, they suggest that the community structure of AOB may be more strongly affected by acidification than that of AOA. The shift in commu- nity structure in both experiments was due to an increase in the relative abundance of one group, whether due to loss of other archetypes or growth of taxa represented by B17 (the probe for the Nitrosomonas ureae clade). In the Monterey Bay experiment, qPCR data indicate that the assemblages are in decline, and the increase in the clade represented by probe B17 may be a result of the decrease in abundance of other archetypes. In the Vineyard Sound experiment, however, the surprising increase in the bacterial amoA gene (Fig. 3) suggests that the increase in relative abundance of clade B17 that was detected on the microarray cannot be due solely to decreases in other clades.

At the time of the array design, probe B17 represented only 3 sequences, including Nitrosomonas ureae as the closest cultured representative. Since that time, with the addition of thousands of new amo $A$ sequences, the probe now represents many more sequences, all of them from uncultured organisms, mostly derived from estuarine or lake sediments. It is not possible to know whether these sequences, which would hybridize with B17, represent organisms with the capacity for urea hydrolysis, but their association with the known organism $N$. ureae supports the possibility. Experiments with pure cultures indicate that the $\mathrm{pH}$ optimum for ureolysis by $N$. ureae is between 6 and 7 (Pommerening-Röser $\&$ Koops 2005), below the $\mathrm{pH}$ in our experiment but nonetheless evidence that these taxa are capable of utilizing urea as a substrate. Thus, one possible mechanism to explain the success of the $N$. ureae clade in our acidification experiments is that they are able to switch to growing on urea as a sole energy source (Pommerening-Röser \& Koops 2005) to survive the decrease in $\mathrm{NH}_{3}$ availability under acidified conditions. Although urea concentrations were not measured in this experiment, previous analysis of the nutrient concentrations in Vineyard Sound indicate that urea concentrations were as large or larger than the concentrations of $\mathrm{NO}_{3}{ }^{-}$and $\mathrm{NH}_{4}{ }^{+}$(Glibert et al. 1985). Additional research will be needed to verify whether these AOB can switch to growth on urea in the face of declining $\mathrm{NH}_{4}{ }^{+}$concentrations. Although ureases have also recently been detected in arctic Thaumarcheaeota (Alonso-Sáez et al. 2012) and in the bathypelagic waters of the Tyrrhenian Sea (Yakimov et al. 2011), this ability is present in only 1 of the 3 complete genomes in the Thaumarcheaeota (Hallam et al. 2006). The lack of response to acidification by AOA suggests that growth on urea may not be a mechanism employed by them in these experiments. 
Second, the relative abundance of AOA and AOB differed between the 2 systems, underscoring the highly variable composition of the total ammonia-oxidizing assemblage. Many studies have reported the numerical dominance of AOA in coastal and marine waters (Mincer et al. 2007, Agogué et al. 2008, Beman et al. 2008, 2012, Bouskill et al. 2012a). Studies from coastal and estuarine sediments, and the water columns of the freshwater reaches of estuaries, however, indicate a greater importance of AOB (Caffrey et al. 2007, Mosier \& Francis 2008, Bouskill et al. 2012a, Cao et al. 2012). In the experiments presented here, the relative abundance of AOB versus AOA varied (Fig. 3). The average AOA:AOB ratio in the Monterey Bay seawater experiment was 0.0014 compared to 3853 in the biofilm from the Vineyard Sound coral experiment. Trait-based modeling of ammonia oxidizer dynamics suggests that as $\mathrm{pH}$ decreases, community diversity will decrease until AOA dominate, although this pattern was not directly observed in comparison with environmental data (Bouskill et al. 2012b). This modeling underscores the challenge in directly linking observable environmental processes, such as the measured reductions in ammonia oxidation (Beman et al. 2012), to patterns in community structure. The data we report here, however, demonstrate that the AOB component of the community is more likely to be altered by future acidification and that continued monitoring of the composition of AOA and AOB communities is needed to understand how ocean acidification could alter oceanic nitrogen cycling.

Determining the contribution of AOA and AOB to marine nitrification is critically important for understanding ecosystem resilience in the face of environmental change. Much more work is needed to assess the biogeographical patterns, and the underlying mechanisms controlling these patterns, for both AOA and AOB. Sequences closely related to Nitrosomonas ureae have been reported from San Francisco Bay (Mosier \& Francis 2008), the Seine River Estuary (Cébron et al. 2003), the Chesapeake Bay (Bouskill et al. 2011), the South China Sea (Cao et al. 2012), and in wetland sediments in Australia (S. Domingos et al. unpubl., GenBank accession no. JF682366), suggesting that this is a widely distributed ammonia-oxidizer clade. If, as our data suggest, the AOB closely related to $N$. ureae play an increasingly important role in ammonia oxidation under acidified conditions, then much more information will be needed regarding the role that urea plays in our understanding of the nitrogen cycle.
Acknowledgements. We thank D. Shi and B. Hopkinson for pH measurements, S. Fawcett for nutrient measurements, and C. Thomas for the chlorophyll a measurements. NSF funding to B.B.W. supported the barrel experiments. E. Gallagher provided advice on statistical approaches. Funding for the coral experiments came from NSF (GRF to M.H.; OCE-1041106), the Woods Hole Oceanographic Institution's Ocean Life Institute, and the International Society for Reef Studies and these experiments were performed with assistance from D. McCorkle and A. Cohen of the Woods Hole Oceanographic Institution. We gratefully acknowledge assistance from D. Storton and the Princeton University Microarray Facility as well as anonymous reviewers who helped improve earlier drafts of this manuscript.

\section{LITERATURE CITED}

Agogué H, Brink M, Dinasquet J, Herndl GJ (2008) Major gradients in putatively nitrifying and non-nitrifying Archaea in the deep North Atlantic. Nature 456:788-791

Alonso-Sáez L, Waller AS, Mende DR, Bakker K and others (2012) Role for urea in nitrification by polar marine Archaea. Proc Natl Acad Sci USA 109:17989-17994

Beman JM, Popp BN, Francis CA (2008) Molecular and biogeochemical evidence for ammonia oxidation by marine Crenarchaeota in the Gulf of California. ISME $\mathrm{J} 2$ : 429-441

Beman JM, Chow CE, King AL, Feng Y and others (2011) Global declines in oceanic nitrification rates as a consequence of ocean acidification. Proc Natl Acad Sci USA 108:208-213

> Beman JM, Popp BN, Alford SE (2012) Quantification of ammonia oxidation rates and ammonia-oxidizing archaea and bacteria at high resolution in the Gulf of California and eastern tropical North Pacific Ocean. Limnol Oceanogr 57:711-726

> Bouskill NJ, Eveillard D, O'Mullan G, Jackson GA, Ward BB (2011) Seasonal and annual reoccurrence in betaproteobacterial ammonia-oxidizing bacterial population structure. Environ Microbiol 13:872-886

Bouskill NJ, Eveillard D, Chien D, Jayakumar A, Ward BB (2012a) Environmental factors determining ammoniaoxidizing organism distribution and diversity in marine environments. Environ Microbiol 14:714-729

Bouskill NJ, Tang J, Riley WJ, Brodie EL (2012b) Trait-based representation of biological nitrification: model development, testing, and predicted community composition. Front Microbiol 3:364

Caffrey JM, Bano N, Kalanetra K, Hollibaugh JT (2007) Ammonia oxidation and ammonia-oxidizing bacteria and archaea from estuaries with differing histories of hypoxia. ISME J 1:660-662

Cao H, Hong Y, Li M, Gu JD (2012) Lower abundance of ammonia-oxidizing archaea than ammonia-oxidizing bacteria detected in the subsurface sediments of the northern South China Sea. Geomicrobiol J 29:332-339

Cébron A, Berthe T, Garnier J (2003) Nitrification and nitrifying bacteria in the lower Seine River and estuary (France). Appl Environ Microbiol 69:7091-7100

> Doney SC, Fabry VJ, Feely RA, Kleypas JA (2009) Ocean acidification: the other $\mathrm{CO}_{2}$ problem. Annu Rev Mar Sci 1:169-192

Fawcett SE, Ward BB (2011) Phytoplankton succession and nitrogen utilization during the development of an 
upwelling bloom. Mar Ecol Prog Ser 428:13-31

Feely RA, Sabine CL, Lee K, Berelson W, Kleypas J, Fabry VJ, Millero FJ (2004) Impact of anthropogenic $\mathrm{CO}_{2}$ on the $\mathrm{CaCO}_{3}$ system in the oceans. Science 305:362-366

Francis CA, Roberts KJ, Beman JM, Santoro AE, Oakley BB (2005) Ubiquity and diversity of ammonia-oxidizing archaea in water columns and sediments of the ocean. Proc Natl Acad Sci USA 102:14683-14688

Glibert PM, Dennett MR, Goldman JC (1985) Inorganic carbon uptake by phytoplankton in Vineyard Sound, Massachusetts. II. Comparative primary productivity and nutritional status of winter and summer assemblages. J Exp Mar Biol Ecol 86:101-118

Hallam SJ, Konstantinidis KT, Putnam N, Schleper C and others (2006) Genomic analysis of the uncultivated marine crenarchaeote Cenarchaeum symbiosum. Proc Natl Acad Sci USA 103:18296-18301

Holcomb M, Cohen AL, McCorkle DC (2012) An investigation of the calcification response of the scleractinian coral Astrangia poculata to elevated $\mathrm{pCO}_{2}$ and the effects of nutrients, zooxanthellae and gender. Biogeosciences 9: 29-39

Joint I, Doney SC, Karl DM (2011) Will ocean acidification affect marine microbes? ISME J 5:1-7

Kitidis V, Laverock B, McNeill LC, Beesley A and others (2011) Impact of ocean acidification on benthic and water column ammonia oxidation. Geophys Res Lett 38:L21603, doi:10.1029/2011GL049095

Krause E, Wichels A, Giménez L, Lunau M, Schilhabel MB, Gerdts G (2012) Small changes in pH have direct effects on marine bacterial community composition: a microcosm approach. PLoS ONE 7:e47035

Kudela RM, Dugdale RC (2000) Nutrient regulation of phytoplankton productivity in Monterey Bay, California. Deep-Sea Res II 47:1023-1053

Mincer TJ, Church MJ, Taylor LT, Preston C, Karl DM, DeLong EF (2007) Quantitative distribution of presumptive archaeal and bacterial nitrifiers in Monterey Bay and the North Pacific Subtropical Gyre. Environ Microbiol 9:1162-1175

> Mosier AC, Francis CA (2008) Relative abundance and diversity of ammonia-oxidizing archaea and bacteria in the San Francisco Bay estuary. Environ Microbiol 10: 3002-3016

> Nicol GW, Leininger S, Schleper C, Prosser JI (2008) The influence of soil $\mathrm{pH}$ on the diversity, abundance and transcriptional activity of ammonia oxidizing archaea and bacteria. Environ Microbiol 10:2966-2978

Oksanen J, Blanchet FG, Kindt R, Legendre P and others (2011) Package 'vegan' version 2.0-2. Available at http://cran.r-project.org/web/packages/vegan/

> Orr JC, Fabry VJ, Aumont O, Bopp L and others (2005) Anthropogenic ocean acidification over the twenty-first century and its impact on calcifying organisms. Nature 437:681-686

Pommerening-Röser A, Koops HP (2005) Environmental $\mathrm{pH}$ as an important factor for the distribution of urease positive ammonia-oxidizing bacteria. Microbiol Res 160: $27-35$

> Rotthauwe JH, Witzel KP, Liesack W (1997) The ammonia monooxygenase structural gene $a m o A$ as a functional marker: molecular fine-scale analysis of natural ammonia-oxidizing populations. Appl Environ Microbiol 63: 4704-4712

Rudd JWM, Kelly CA, Schindler DW, Turner MA (1988) Disruption of the nitrogen cycle in acidified lakes. Science 240:1515-1517

Santoro AE, Casciotti KL, Francis CA (2010) Activity, abundance and diversity of nitrifying archaea and bacteria in the central California Current. Environ Microbiol 12: 1989-2006

Shi D, Xu Y, Morel FMM (2009) Effects of the $\mathrm{pH} / \mathrm{pCO}_{2}$ control method on medium chemistry and phytoplankton growth. Biogeosciences 6:1199-1207

> Ward B (2008) Phytoplankton community composition and gene expression of functional genes involved in carbon and nitrogen assimilation. J Phycol 44:1490-1503

Ward BB, Eveillard D, Kirshtein JD, Nelson JD, Voytek MA, Jackson GA (2007) Ammonia-oxidizing bacterial community composition in estuarine and oceanic environments assessed using a functional gene microarray. Environ Microbiol 9:2522-2538

Yakimov MM, Cono VL, Smedile F, DeLuca TH and others (2011) Contribution of crenarchaeal autotrophic ammonia oxidizers to the dark primary production in Tyrrhenian deep waters (Central Mediterranean Sea). ISME J 5:945-961

Yool A, Martin AP, Fernández C, Clark DR (2007) The significance of nitrification for oceanic new production. Nature 447:999-1002

Zhang H, Byrne RH (1996) Spectrophotometric pH measurements of surface seawater at in-situ conditions: absorbance and protonation behavior of thymol blue. Mar Chem 52:17-25 


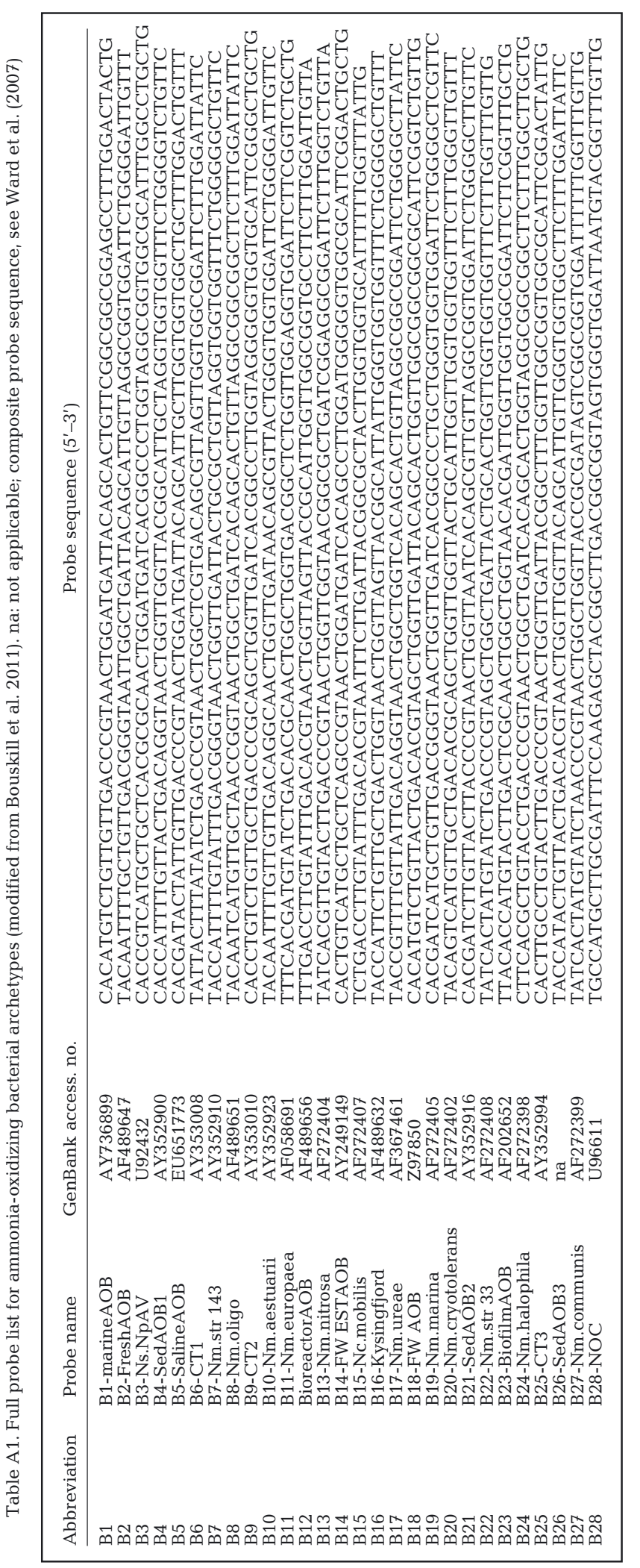

Editorial responsibility: Ronald Kiene,

Mobile, Alabama, USA

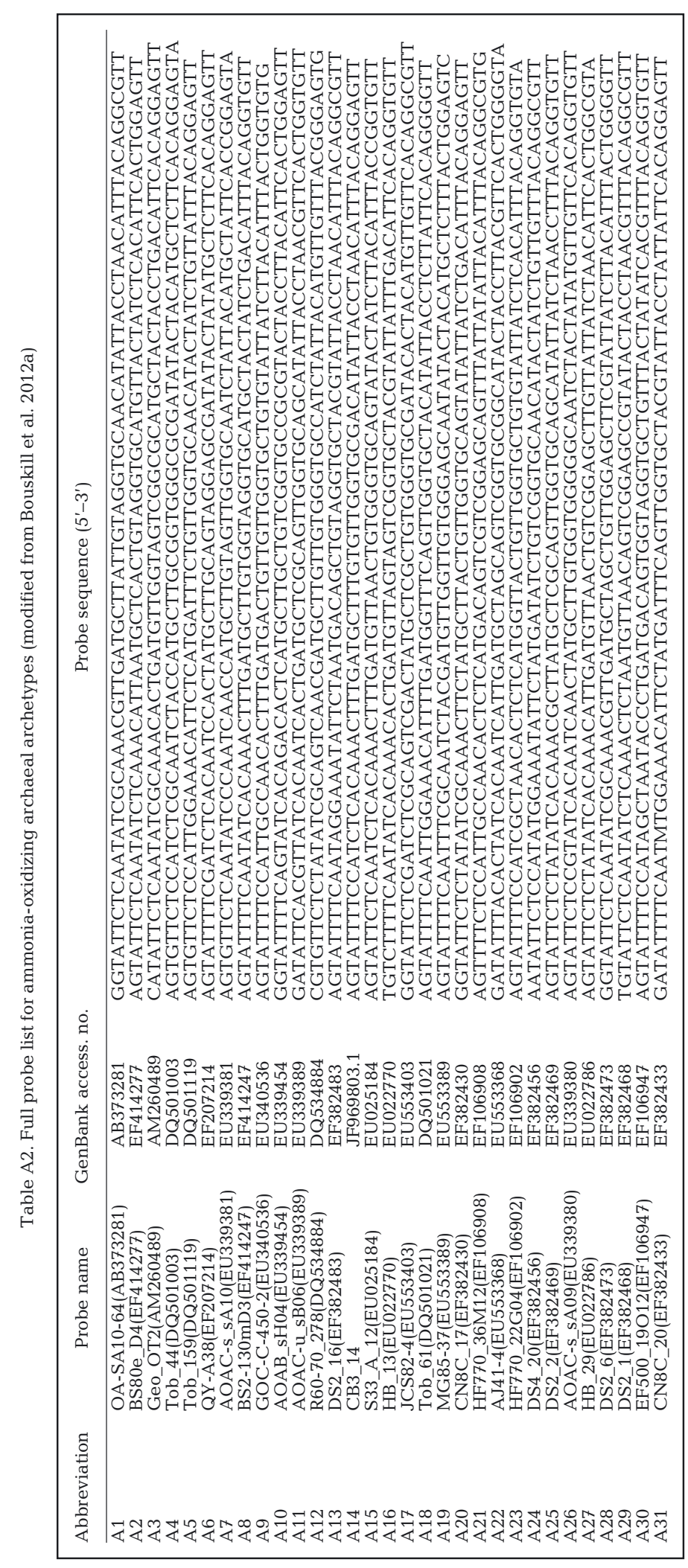

Submitted: April 29, 2013; Accepted: August 16, 2013

Proofs received from author(s): September 18, 2013 